\title{
Peningkatan Keterampilan bagi Pengelola dan Anggota Badan Usaha Milik Desa di Desa Amokuni, Kecamatan Ranomeeto Barat, Kabupaten Konawe Selatan, Sulawesi Tenggara
}

\section{(Skill Improvement for Managers and Members of Village-Owned Enterprises in Amokuni Village, West Ranomeeto Subdistrict, South Konawe District, Southeast Sulawesi)}

\author{
Arifuddin Mas'ud1, Sapto Raharjo ${ }^{2}$, Weka Gusmiarty Abdullah ${ }^{3}{ }^{*}$, Emilia Nurdin', Santiadji Mustafa1 $^{1}$ \\ ${ }^{1}$ Jurusan Akuntansi, Fakultas Ekonomi dan Bisnis, Universitas Halu Oleo, Kampus Hijau Bumi Tridharma Jl. H.E.A \\ Mokodompit Anduonohu, Kec. Kambu, Kota Kendari, Sulawesi Tenggara 93232. \\ 2 Jurusan Kimia, Fakultas Matematika dan IlmuPengetahuan Alam, Universitas Halu Oleo, Kampus Hijau Bumi Tridharma Jl. \\ H.E.A Mokodompit Anduonohu, Kec. Kambu, Kota Kendari, Sulawesi Tenggara 93232. \\ 3 Jurusan Agribisnis, Fakultas Pertanian, Universitas Halu Oleo, Kampus Hijau Bumi Tridharma Jl. H.E.A Mokodompit \\ Anduonohu, Kec. Kambu, Kota Kendari, Sulawesi Tenggara 93232. \\ *Penulis Korespondensi: weka.gusmiarty_faperta@uho.ac.id \\ Diterima Januari 2020/Disetujui Februari 2021
}

\begin{abstract}
ABSTRAK
Kegiatan pengabdian masyarakat ini bertujuan untuk meningkatkan pengetahuan, dan memberikan keterampilan kepada pengelola dan anggota Badan Usaha Milik Desa (Bumdes) Amokuni mengenai manajemen usaha, peningkatan nilai tambah, penentuan harga pokok produksi (HPP), dan strategi pemasaran kreatif. Kegiatan yang dilaksanakan meliputi sosialisasi, penyuluhan, pelatihan, dan pendampingan. Hasil dari kegiatan pengabdian ini adalah meningkatnya pengetahuan dan keterampilan pengelola dan anggota Bumdes Amokuni. Peningkatan pengetahuan dimaksud dalam hal manajemen usaha, peningkatan nilai tambah sumber daya air tawar, penentuan HPP, dan strategi pemasaran kreatif untuk produk ikan air tawar yang akan dihasilkan. Peningkatan keterampilan dimaksud berupa keterampilan membuat konsep manajemen usaha, mengolah ikan bawal dan nila menjadi abon ikan kriuk, dan stik tulang ikan dengan lima varian rasa (rasa original, BBQ, pedas manis, balado, dan jagung bakar), menentukan HPP, dan memasarkan diversifikasi produk ikan air tawar tersebut secara online dan offline.
\end{abstract}

Kata kunci: harga pokok produksi, keterampilan, manajemen, nilai tambah, strategi pemasaran kreatif

\begin{abstract}
The objective of this community service activity are to increase knowledge and skills to managers and members of Amokuni Village Owned Enterprise (Bumdes Amokuni) regarding business management, added value, determining the cost of goods manufactured (HPP), and creative marketing strategies. Activities carried out include socialization, extention, training and mentoring. The result of this service activity was that the knowledge and skills of the managers and members of Bumdes Amokuni have increased. Increased knowledge was meant in terms of business management, increasing the added value of freshwater resources, HPP determining and creative marketing strategies for freshwater fish products to be produced. Improved skills were in the form of skills in making business management concepts, processing pomfret and tilapia into shredded fish and fishbone sticks with 5 flavors (original taste, BBQ, spicy sweet, balado, and roasted corn), HPP determining, and marketing diversified products freshwater fish online and offline.
\end{abstract}

Keywords: cost of goods manufactured (HPP), creative marketing strategies, management, skill, value added

\section{PENDAHULUAN}

Badan Usaha Milik Desa berdiri dengan dilandasi oleh UU Nomor 32 Tahun 2004 tentang Pemerintahan Daerah Pasal 213 ayat (1) disebutkan bahwa: desa dapat mendirikan badan usaha milik desa sesuai dengan kebutuhan dan potensi desa, turut menjadi pondasi penting dalam pendirian BUM Desa. Badan usaha milik Desa (atau diakronimkan menjadi Bumdes) merupakan usaha desa yang dibentuk oleh pemerintah desa yang kepemilikan modal dan pengelolaannya dilakukan oleh pemerintah desa dan masyarakat (Peraturan Menteri Dalam 
Negeri Nomor 39 Tahun 2010). Bumdes memiliki banyak sumber permodalan, di antaranya berasal dari pemerintah desa, tabungan masyarakat, bantuan pemerintah, pemerintah provinsi dan pemerintah kabupaten/kota, pinjaman, atau penyertaan modal pihak lain atau kerja sama bagi hasil atas dasar saling menguntungkan. Sumber permodalan Bumdes lainnya dapat berasal dari pinjaman. Bumdes dapat melakukan pinjaman setelah mendapat persetujuan dari Badan Permusyawaratan Desa (BPD), dengan demikian keberadaan Bumdes sangat potensial dalam meningkatkan kemandirian desa melalui keberdayaan masyarakatnya.

Besarnya potensi Bumdes dalam memandirikan desa tersebut hingga kini masih terkendala dalam realisasinya. Hal ini karena masih banyak terdapat kelemahan, terutama kemampuan manajemen dan kreativitas usaha (Berdesa 2017). Bumdes seharusnya tidak boleh dipandang lemah lalu dimanfaatkan hanya karena kemampuan manajemen yang masih lemah. Salah satu Bumdes di wilayah Sulawesi Tenggara, khususnya di Kabupaten Konawe Selatan yang juga masih menghadapi masalah manajemen dan kreativitas usaha di tengah besarnya potensi desa yang tersedia adalah Bumdes di Desa Amokuni, Kecamatan Ranomeeto Barat. Jenis usaha utama Bumdes Amokuni adalah usaha budi daya ikan air tawar. Pemilihan jenis usaha ini didasari oleh sumber daya air tawar di Desa Amokuni. Udhyn (2017) menuliskan bahwa Desa Amokuni merupakan satu-satunya desa di Kabupaten Konawe Selatan yang wilayahnya dialiri sungai.

Bumdes Amokuni hingga saat ini belum berkembang maksimal karena dua hal, yaitu pertama, belum optimalnya manajemen usaha serta belum ada diversifikasi usaha yang dilakukan untuk peningkatan nilai tambah ikan air tawar yang dibudidayakan (ikan nila dan bawal) dan kedua, belum diaplikasikannya strategi pemasaran kreatif bagi produk-produk Bumdes. Ohoiwutun et al. (2017) juga mengidentifikasi bahwa masih rendahnya kualitas suatu usaha dilatarbelakangi oleh keterbatasan pengetahuan dan pendidikan, kurangnya modal, promosi serta belum adanya upaya pemasaran dengan memanfaatkan media sosial yang ada. Kusnayadi et al. (2019) juga menyampaikan bahwa rendahnya kualitas usaha tidak terlepas dari kurangnya keterampilan dan pengetahuan dalam membuat variasi produk yang memiliki cita rasa enak dan berkualitas, serta variasi bentuk produk, kurangnya pengetahuan dalam bidang perencanaan pemasaran. Lebih lanjut dikatakan pula oleh Ohoiwutun et al. (2017) bahwa potensi sumber daya perikanan yang besar memerlukan pengembangan dan pengolahan lanjutan yang lebih terarah pada peningkatan kesejahteraan masyarakat. Oleh karena itu, sangat perlu dilakukan kegiatan pengabdian masyarakat untuk peningkatan kualitas Bumdes Amokuni melalui beberapa tahapan kegiatan, yaitu sosialisasi, penyuluhan, pelatihan, dan pendampingan guna meningkatkan kualitas dan kuantitas hasil produksi secara berkelanjutan.

Tujuan kegiatan pengabdian pada masyarakat ini adalah untuk, meningkatkan pengetahuan, dan memberikan keterampilan kepada pengelola dan anggota Bumdes Amokuni mengenai perbaikan manajemen usaha, peningkatan nilai tambah, penentuan harga pokok produksi (HPP), dan strategi pemasaran kreatif. Peningkatan keterampilan pengelola dan anggota Bumdes Amokuni ini diharapkan dapat meningkatkan kesejahteraan pengelola dan anggota Bumdes Amokuni dan menyebar hingga ke sebagian besar masyarakat Desa Amokuni.

\section{METODE PELAKSANAAN KEGIATAN}

Kegiatan ini merupakan kegiatan pengabdian pada masyarakat yang terintegrasi dengan program Kuliah Kerja Nyata (KKN) tematik. Metode pelaksanaan kegiatan ini dideskripsikan dalam beberapa hal, yaitu lokasi dan partisipan, bahan dan alat, serta metode pelaksanaan kegiatan.

\section{Lokasi dan Partisipan}

Kegiatan ini dilaksanakan pada bulan Agustus 2019 di Desa Amokuni, Kecamatan Ranomeeto Barat, Kabupaten Konawe Selatan, Sulawesi Tenggara. Partisipan utama kegiatan ini adalah pengelola dan anggota Bumdes Amokuni yang terdiri dari ketua, sekretaris dan bendahara. partisipan pendukung adalah ibu-ibu anggota aktif Bumdes Amokuni, yaitu sebanyak 10 orang. Semua partisipan pendukung ini adalah masyarakat Desa Amokuni yang selalu berpartisipasi aktif di setiap kegiatan usaha bersama pengelola dan anggota Bumdes Amokuni.

\section{Bahan dan Alat}

Bahan dan alat yang digunakan dalam kegiatan ini sebagai berikut:

- Kegiatan penyuluhan, bahan yang digunakan: kertas, paket internet, dan spanduk. Alat yang 
digunakan: white board, spidol, pulpen, dan HP android.

- Kegiatan pelatihan, bahan yang digunakan: kertas, ikan nila, ikan bawal, tepung tapioka, bawang putih, garam, penyedap rasa, air, minyak goreng, gas, plastik kemasan, label kemasan, spanduk. Alat yang digunakan: white board, spidol, pulpen, wajan, dandang, kompor, tabung gas, blender, timbangan, baskom kecil, tapis, sude, pisau, stick roll, dan mesin press.

- Kegiatan pendampingan, bahan yang digunakan: paket internet. Alat yang digunakan: handphone (HP) android.

\section{Metode Pelaksanaan Kegiatan}

Metode yang digunakan dalam kegiatan pengabdian ini adalah metode persuasif pendekatan, penyuluhan, pelatihan, dan pendampingan bagi pengelola dan anggota Bumdes Amokuni.

- Metode persuasif dilakukan untuk tujuan sosialisasi kegiatan. Ini dilakukan dengan dua kali kunjungan ke pengelola dan anggota Bumdes Amokuni, dilanjutkan dengan satu kali kegiatan pertemuan dan diskusi yang difasilitasi oleh Kepala Desa Amokuni dan Ketua Bumdes Amokuni

- Metode penyuluhan digunakan untuk memberikan pemahaman mengenai manajemen usaha, penentuan harga pokok produksi (HPP), peningkatan nilai tambah produk ikan air tawar, dan strategi pemasaran kreatif.

- Metode pelatihan sangat penting untuk memberikan petunjuk praktis pelaksanaan tentang berbagai pemahaman materi yang telah diberikan pada kegiatan penyuluhan. Metode pelatihan juga dapat memperpendek waktu belajar para pengelola dan anggota Bumdes Amokuni agar lebih kompeten dalam pengelolaan Bumdes. Pelatihan ini dilaksanakan sebanyak empat kali, yaitu Tanggal 10, 12, 14, dan 16 Agustus.

- Metode pendampingan dilakukan untuk memastikan implementasi yang baik dan benar dari materi penyuluhan dan pelatihan yang telah diberikan sebelumnya sehingga tujuan kegiatan ini dapat tercapai sesuai harapan.

\section{HASIL DAN PEMBAHASAN}

Kegiatan pengabdian pada masyarakat ini dilakukan untuk meningkatkan keterampilan pengelola dan anggota Bumdes di Desa Amokuni,
Kecamatan Ranomeeto Barat, Kabupaten Konawe Selatan. Kegiatan ini terdiri atas kegiatan utama, yaitu 1) Sosialisasi; 2) Penyuluhan; 3) Pelatihan; dan 4) Pendampingan.

\section{Sosialisasi Kegiatan}

Sosialisasi adalah proses interaksi sosial untuk mengenal cara-cara berpikir, berperasaan dan berperilaku agar dapat berperan secara efektif dalam masyarakat (Soe'oed dalam Ihromi (2004). Dengan demikian kegiatan sosialisasi ini penting dilakukan di awal kegiatan pengabdian sehingga dapat lebih mengenal partisipan atau sasaran kegiatan.

Sosialisasi kegiatan ini dilakukan dua minggu sebelum tahapan kegiatan penyuluhan dilaksanakan. Sosialisasi kegiatan diawali tim pengabdi dengan mengunjungi Kepala Desa Amokuni untuk menjalin silaturahmi disertai dengan penyampaian rencana dan programprogram kegiatan pengabdian yang akan dilaksanakan (Gambar 1). Pada saat itu juga direncanakan waktu pertemuan dengan perangkat Desa Amokuni, pengelola dan anggota aktif Bumdes.

Kegiatan inti sosialisasi dilaksanakan pada 28 Juli 2019 di Balai Desa Amokuni. Kegiatan sosialisasi dihadiri oleh kepala desa, sekretaris desa, pengelola, dan anggota aktif dari Bumdes Amokuni. Pada saat ini disampaikan programprogram kegiatan dan rencana waktu pelaksanaannya oleh tim pengabdi, dengan mempertimbangkan berbagai saran yang disampaikan oleh peserta sosialisasi.

Peserta kegiatan sosialisasi sangat antusias mendengar rencana program kegiatan pengabdian masyarakat ini. Antusiasme peserta kegiatan sosialisasi ditunjukkan dengan permintaan mereka kepada tim pengabdi untuk segera menentukan waktu-waktu tiap tahapan kegiatan pengabdian sehingga mereka bisa

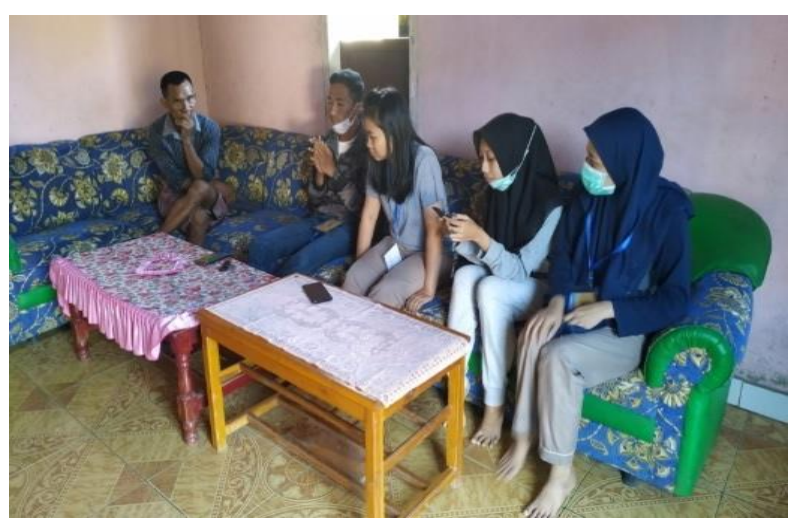

Gambar 1 Sosialisasi kegiatan kepada kepala desa. 
menyesuaikan dengan kegiatan-kegiatan lainnya. Mereka juga aktif menyampaikan pendapat dan saran-saran untuk memperlancar terlaksananya rangkaian kegiatan pengabdian yang direncanakan. Hal ini karena mereka merasa belum berpartisipasi maksimal dalam aktivitas Bumdes Amokuni, juga belum merasakan manfaat yang maksimal dari Bumdes Amokuni. Mereka bahkan menyarankan agar sebelum pelaksanaan pelatihan peningkatan nilai tambah ikan air tawar dilakukan survei ke tambak-tambak ikan para anggota aktif Bumdes. Hal ini dilakukan untuk memperoleh bahan baku ikan air tawar yang memenuhi syarat kualitas dan kuantitas untuk diolah menjadi abon ikan dan stik tulang ikan.

Tidak ada hambatan dalam kegiatan sosialisasi ini. Hasil kegiatan ini adalah disepakatinya waktu pelaksanaan penyuluhan pada 8 Agustus 2019, pelatihan membuat konsep manajemen usaha Bumdes Amokuni pada 10 Agustus 2019, pelatihan peningkatan nilai tambah melalui pengolahan ikan nila dan ikan bawal menjadi abon dan stik ikan pada 12 Agustus 2019, pelatihan penentuan harga pokok produksi (HPP) pada 14 Agustus 2019, pelatihan strategi pemasaran kreatif pada 16 Agustus 2019, mengikuti pameran pangan lokal se Kabupaten Konawe Selatan dalam rangka perayaan kemerdekaan pada Tanggal 17 Agustus 2019. Kegiatan pendampingan dilakukan sejak saat selesainya pelatihan hingga 28 Agustus 2019. Hal lain yang disepakati juga adalah masyarakat bersedia membantu menyediakan segala kelengkapan dalam pelaksanaan berbagai tahapan kegiatan yang direncanakan tersebut.

\section{Penyuluhan}

Penyuluhan merupakan sistem belajar untuk menjadi mau, tahu, dan bisa menyelesaikan masalah yang dihadapi (Mardikanto 1993). Penyuluhan juga dapat diartikan sebagai perubahan perilaku (sikap, pengetahuan, dan keterampilan) petani, sehingga fungsi penyuluhan dapat tercapai, yaitu sebagai penyebar inovasi, penghubung antara petani, penyuluh dan lembaga penelitian, melaksanakan proses pendidikan khusus, yaitu pendidikan praktis dalam bidang pertanian dan mengubah perilaku lebihmenguntungkan (Levis 1996). Oleh karena itu, kegiatan penyuluhan diperlukan dalam implementasi program peningkatan kualitas Bumdes Amokuni sebagai upaya untuk membuka wawasan dan menambah pengetahuan pengelola dan anggota Bumdes dan para anggota aktif mengenai manajemen usaha, peningkatan nilai tambah sumber daya air tawar, penentuan harga pokok produksi (HPP), dan strategi pemasaran kreatif. Pada kegiatan ini juga diberikan motivasi kepada peserta agar memiliki kesadaran dan semangat untuk bahu membahu meningkatkan kualitas Bumdes Amokuni sehingga ke depannya dapat lebih bermanfaat dalam upaya peningkatan kesejahteraan bersama.

Kegiatan penyuluhan berjalan dengan lancar (Gambar 2). Peserta kegiatan penyuluhan menyimak dengan baik materi-materi yang diberikan oleh tim pengabdi. Mereka cukup antusias menerima materi-materi yang diberikan terutama pada materi peningkatan nilai tambah melalui pengolahan abon dan stik ikan. Hal ini ditunjukkan dengan banyaknya peserta $(80 \%)$ yang memberikan pertanyaan dan saran mengenai teknis pembuatan dan pemasaran abon dan stik tulang ikan.

Hasil kegiatan penyuluhan ini menunjukkan a) Terjadinya peningkatan pengetahuan $80 \%$ peserta terhadap pentingnya manajemen usaha, peningkatan nilai tambah sumber daya air tawar, penentuan HPP dan strategi pemasaran kreatif untuk produk ikan air tawar yang akan dihasilkan dan b) Munculnya keinginan peserta untuk meningkatkan keterampilannya dalam pengolahan dan pemasaran produk abon dan stik tulang ikan. Hal ini sebagaimana hasil pengabdian Ohoiwutun et al. (2017) bahwa kegiatan penyuluhan dan pelatihan efektif dalam transfer ilmu pengetahuan dan teknologi sehingga terjadi peningkatan pengatahuan.

\section{Pelatihan}

Pelatihan diartikan sebagai suatu proses di mana orang-orang mencapai kemampuan tertentu untuk membantu mencapai tujuan organisasi (Robert 2002). Dengan demikian kegiatan pelatihan ini sangat penting melengkapi program peningkatan keterampilan pengelola dan anggota Bumdes Amokuni mengenai manajemen usaha,

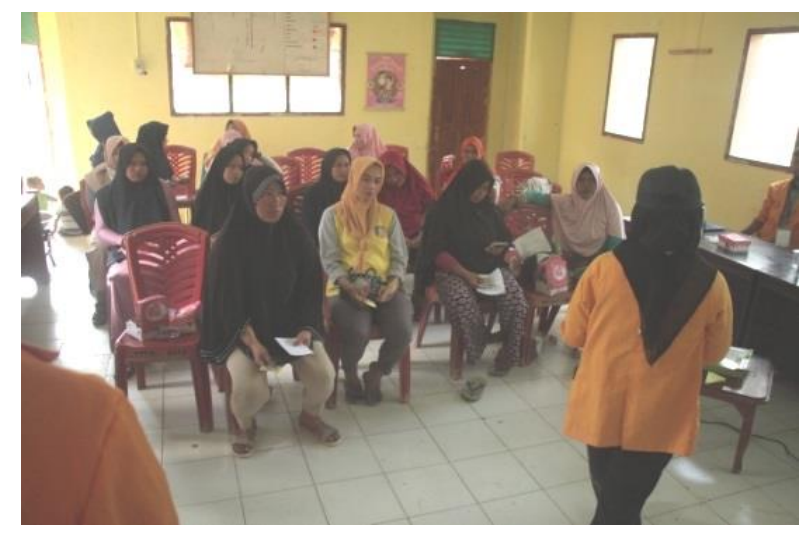

Gambar 2 Penyuluhan kepada anggota Bumdes. 
peningkatan nilai tambah, penentuan HPP, dan strategi pemasaran kreatif.

Kegiatan pelatihan dilaksanakan dengan topik yang berbeda-beda, yaitu 1) Pelatihan membuat konsep manajemen usaha Bumdes; 2) Peningkatan nilai tambah melalui pengolahan ikan nila dan ikan bawal menjadi abon dan stik ikan; 3) Penentuan harga pokok produksi (HPP); dan 4) Strategi pemasaran kreatif. Pelatihan ini dilaksanakan sebanyak empat kali berdasarkan waktu yang telah disepakati saat sosialisasi kegiatan.

\section{Pelatihan Membuat Konsep Manajemen Usaha Bumdes}

Pelatihan membuat konsep manajemen usaha Bumdes khusus diperuntukkan bagi pengelola dan anggota Bumdes, yaitu ketua, sekretaris, dan bendahara. Pelatihan ini dilaksanakan pada 10 Agustus 2019. Pelatihan manajemen usaha ini sangat penting sebagai guide line bagi pelaksanaan usaha secara rutin maupun dalam upaya peningkatan kualitas Bumdes mengingat peran penting manajemen sebagaimana yang dinyatakan oleh Siswanto (2005) bahwa manajemen adalah seni dan ilmu dalam perencanaan, pengorganisasian, pengarahan, pemotivasian, dan pengendalian terhadap orang dan mekanisme kerja untuk mencapai tujuan. Seni dan ilmu dalam pengusahaan produk ikan air tawar harus diterapkan secara lebih kreatif, tidak hanya pada aspek produksi tetapi juga pada aspek pemasarannya. Dengan demikian, dapat diwujudkan peningkatan kuantitas, kualitas, dan pengemasan.

Pelatihan diawali dengan memberikan sedikit pengulangan teori manajemen dan langsung memberikan praktik membuat konsep manajemen usaha yang baik dan benar yang mencakup empat unsur, yaitu perencanaan (planning), pengorganisasian sumber daya (organizing), pengarahan (directing), pengendalian (controlling), dan evaluasi (evaluation). Fungsi manajemen ini sebagaimana yang dikemukakan oleh Terry (2009) bahwa bahwa fungsi-fungsi yang ada dalam manajemen yang bersifat aktivitas meliputi perencanaan (planning), pengorganisasian (organizing), penggerakan (actuating), dan pengawasan (controlling).

Perumusan konsep manajemen usaha Bumdes berdasarkan kelima fungsi manajemen ini dipraktikkan sebagai berikut:

- Perencanaan; pengelola dan anggota Bumdes Amokuni menuliskan tujuan Bumdes yang akan dicapai dan menuliskan rencana cara- cara terbaik untuk mencapai tujuan tersebut. Selanjutnya, pengelola dan anggota Bumdes diarahkan untuk merencanakan beberapa di antaranya jenis-jenis usaha yang akan dilakukan, sumber-sumber bahan baku dan penolong, sumber daya manusia, teknis produksi, strategi pemasaran, dan rencana anggaran belanja.

- Pengorganisasian; pengelola dan anggota Bumdes menuliskan pembagian tugas dan tanggung jawab tiap pengelola dan anggota Bumdes dan anggota aktif, yaitu siapa mengerjakan apa, siapa bertanggung jawab apa, dan siapa saja yang berwenang mengambil keputusan.

- Pengarahan; pengelola dan anggota Bumdes terutama ketua Bumdes menuliskan dan mendeskripsikan metode-metode yang akan dilaksanakan untuk melakukan pengarahan, motivasi dan transparansi pengelolaan Bumdes kepada pengelola dan anggota Bumdes lainnya dan para anggota aktif.

- Pengendalian; pengelola dan anggota Bumdes menuliskan standar dan kriteria-kriteria ketercapaian tujuan yang telah ditetapkan, juga menuliskan cara-cara perbaikan jika nantinya ditemukan penyimpangan dari standar pencapaian tujuan yang telah ditetapkan.

Pengelola dan anggota Bumdes Amokuni merespons baik pelatihan ini. Mereka mengikuti dengan baik penyampaian materi oleh tim pengabdi dan segera mempraktikkan materi yang diperoleh dalam pembuatan konsep manajemen usaha. Pengelola dan anggota Bumdes Amokuni menyampaikan bahwa dengan adanya konsep manajemen usaha tersebut menjadi lebih optimis untuk mengembangkan diversifikasi usaha yang dapat membantu peningkatan kesejahteraan masyarakat Desa Amokuni.

\section{Pelatihan Peningkatan Nilai Tambah Sumber Daya Air Tawar}

Peningkatan nilai tambah produk sangat penting bagi peningkatan kualitas usaha Bumdes Amokuni. Menurut Sudiyono (2002) bahwa nilai tambah merupakan proses pengolahan bahan yang menyebabkan adanya pertambahan nilai produksi. Peningkatan nilai tambah pada Bumdes Amokuni dilakukan dengan melakukan diversifikasi sumber daya ikan air tawar, berupa pengolahan stik tulang ikan dan abon ikan bawal dan nila. Hal ini sesuai dengan hasil-hasil kegiatan pengabdian sebelumnya bahwa perubahan bentuk segar menjadi bentuk olahan dapat meningkatkan nilai tambah seperti pada produk 
kopi laos dan kunyit putih (Nuzuliyah 2018), agroindustri chips jagung (Rahman 2015), olahan es krim rumput laut (Fausayana et al. 2019), olahan kripik pisang aneka rasa (Hartoyo et al. 2019).

Kegiatan pelatihan peningkatan nilai tambah ini dilaksanakan pada 12 Agustus 2019 yang dihadiri oleh pengelola dan 10 orang ibu-ibu anggota aktif Bumdes Amokuni (Gambar 3). Bahan yang diperlukan pada pelatihan ini disiapkan oleh tim pengabdian sedangkan peralatan disiapkan oleh peserta pelatihan. Peserta pelatihan dibagi menjadi dua kelompok (masingmasing kelompok lima orang). Satu kelompok mengolah ikan bawal dan nila menjadi abon ikan, dan kelompok lainnya mengolah ikan bawal dan nila menjadi stik tulang ikan.

Tahap awal pengolahan abon ikan dan stik tulang ikan dilakukan secara bersama oleh kedua kelompok peserta. Hal ini karena penggunaan bahan baku yang sama, juga sama proses awal pengerjaan yang juga sama. Proses awal yang dimaksud adalah mengkukus ikan bawal dan nila, pemisahan antara daging dan tulang ikan. Proses pengolahan detail sebagaimana pada Gambar 4 dan 5 .

Abon ikan dibuat hanya rasa original. Perbedaan dengan abon ikan yag telah ada adalah
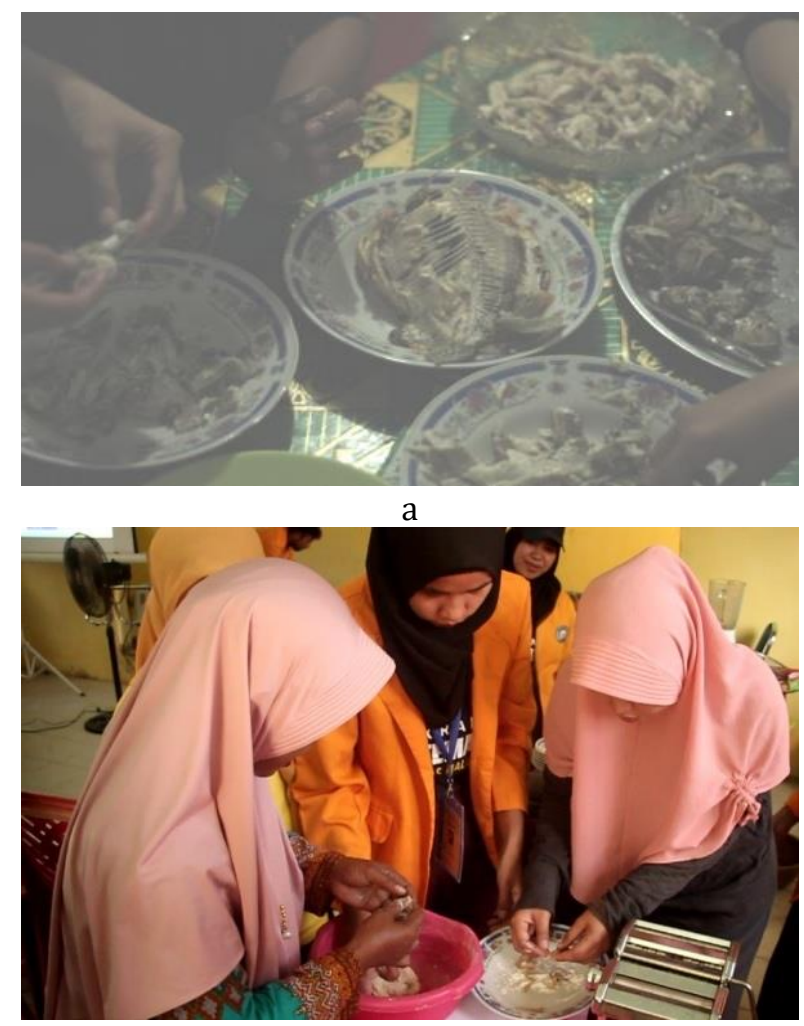

C abon ikan bawal dan nila ini dibuat agak garing dan renyah sehingga dinamakan abon kriuk. Sementara stik tulang ikan bawal dan nila dibuat menjadi 5 rasa, yaitu rasa original, BBQ, Pedas manis, Balado, dan jagung bakar. Setelah produk abon ikan dan stik tulang ikan jadi, dilanjutkan dengan pengemasan dan pelabelan. Pendesainan label kemasan dilakukan oleh tim pengabdian dengan mempertimbangkan sumbang saran dari peserta saat kegiatan penyuluhan. Kedua produk ini diberi merk Bon-kuni.

Pemasaran produk ikan air tawar seringkali tanpa pengemasan. Hal ini disebabkan pangsa pasarnya adalah konsumen di pasar-pasar tradesional. Tidak adanya pengemasan menyebabkan produk ini belum bisa diterima di pasar-pasar modern (swalayan dan toserba) ataupun diperdagangkan antar pulau. Oleh karena itu, sangat diperlukan transfer teknologi pengemasan produk ikan air tawar dan olahannya untuk lebih meningkatkan nilai tambahnya.

Kegiatan pelatihan ini ditanggapi dengan positif oleh para anggota aktif Bumdes Amokuni. Mereka sangat antusias dalam kegiatan ini, terlebih lagi karena bahan baku ikan bawal dan nila yang digunakan tidak ada yang terbuang, semua bagian ikan temanfaatkan dan bernilai jual. Selama proses berlangsung peserta

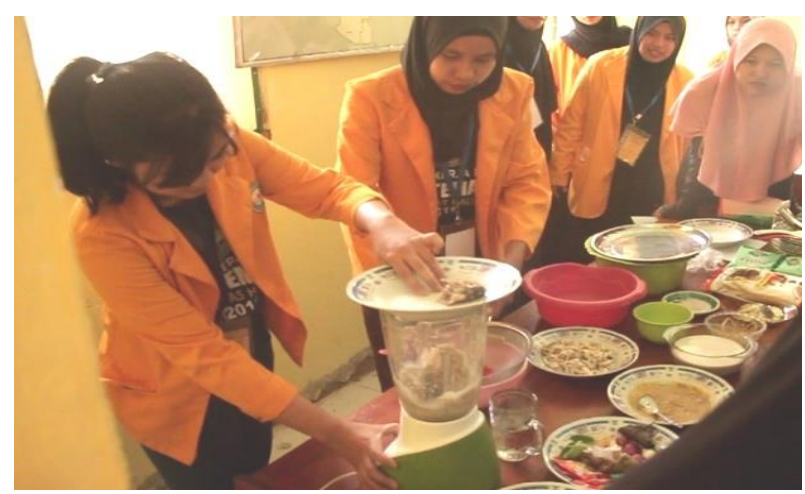

b

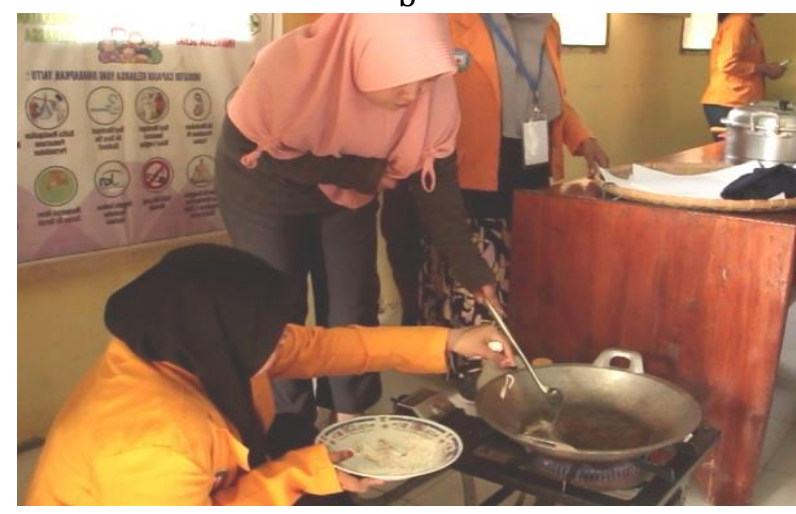

d

Gambar 3 a) Persiapan bahan-bahan; b) Pengolahan abon ikan; c) Pengolahan stik tulang ikan; dan d) Penggorengan abon dan stik tulang ikan. 


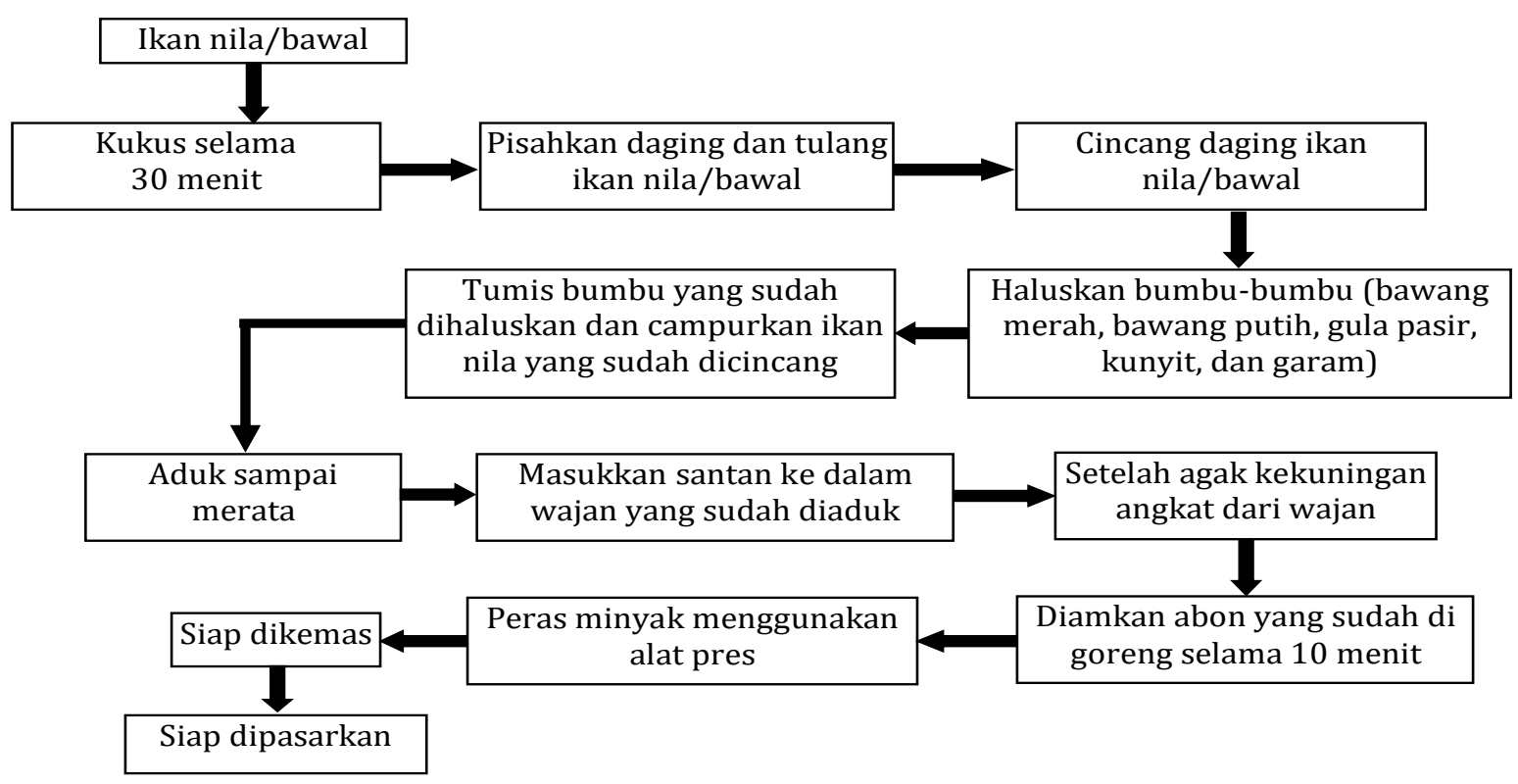

Gambar 4 Proses pembuatan abon ikan.

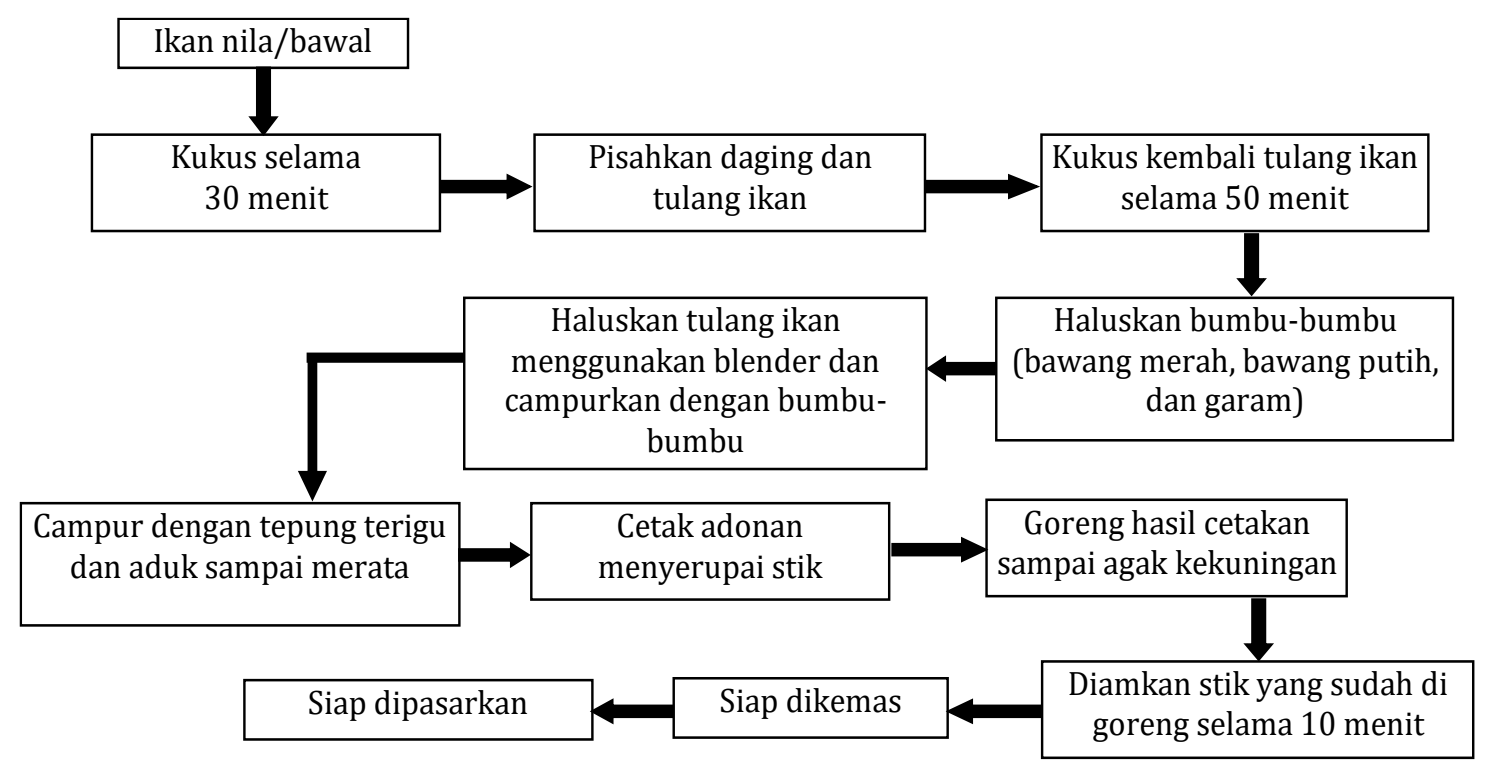

Gambar 5 Proses pembuatan stik tulang ikan.

menyampaikan beberapa pertanyaan yang mendorong semakin efektifnya kegiatan ini. Kegiatan pelatihan juga berjalan dengan serius tapi santai. Para peserta seringkali bekerja disertai humorhumor ringan. Satu-satunya kendala yang dihadapi dalam pelatihan ini adalah kurang memadainya keteresediaan bahan baku. Ikan bawal dan nila yang dibudidayakan belum banyak yang memasuki umur panen sehingga volume dagingnya belum maksimal.

\section{Pelatihan Penentuan Harga Pokok Produksi (HPP)}

Selanjutnya pada 14 Agustus 2019 dilaksanakan pelatihan penentuan harga pokok produksi (HPP). Harga pokok produksi adalah harga pokok produksi mencerminkan total biaya barang yang diselesaikan selama pembuatan produk yang mencakup biaya produksi dan nonproduksi (Hansen \& Mowen 2006). Biaya produksi adalah biaya-biaya yang dikeluarkan dalam pengolahan bahan baku menjadi produk jadi, seperti bahan baku langsung, tenaga kerja langsung dan biaya overhead pabrik, sedangkan biaya non produksi adalah biaya-biaya yang dikeluarkan untuk kegiatan non produksi, seperti biaya pemasaran dan biaya administrasi dan umum.

Semua jenis usaha yang dilakukan bertujuan utama mendapatkan keuntungan guna peningkatan kualitas usaha dan kesejahteraan pengelolanya, demikian juga pada Bumdes 
Amokuni. Keuntungan dapat diperoleh salah satunya dengan penentuan harga jual yang tepat melalui penentuan harga pokok produksi (HPP). Hal ini sebagaimana yang dikemukakan oleh Mulyadi (2012) bahwa HPP bermanfaat untuk menentukan harga jual, memantau realisasi biaya produksi, menghitung laba atau rugi, dan menentukan harga pokok persediaan produk jadi dan produk dalam proses yang disajikan dalam neraca.

Peserta kegiatan ini sama dengan peningkatan nilai tambah sumber daya air tawar, yaitu anggota aktif dan dan pengelola dan anggota Bumdes Amokuni. Sebagaimana pada pelatihan sebelumnya, peserta pelatihan dibagi menjadi dua kelompok, sesuai dengan pembagian kelompok sebelumnya, yaitu kelompok abon ikan dan kelompok stik tulang ikan.

Masing-masing kelompok didampingi oleh tim pengabdian untuk menuliskan dengan detail setiap bahan dan alat yang digunakan dalam pembuatan abon ikan dan stik tulang ikan disertai dengan jumlah dan harga/perkiraan harganya masing-masing (Gambar 6). Perkiraan harga yang dimaksud adalah bagi bahan yang diproduksi sendiri atau tidak dibeli sehingga diperlukan perkiraan harga sekiranya bahan tersebut benar-benar dibeli. Demikian pula untuk alat-alat yang digunakan jika alat tersebut tidak benar-benar dibeli. Hal ini penting untuk menghasilkan nilai HPP yang real. Penentuan HPP seperti ini sangat penting untuk keberlanjutan usaha pengolahan abon ikan kriuk dan stik tulang ikan. Pada usaha yang berkembang memungkinkan adanya penambahan bahan dan alat yang digunakan yang tidak lagi hanya bersumber dari apa yang diproduksi sendiri sehingga memerlukan modal untuk pembeliannya.

Peserta pelatihan merasa sangat terbantu dengan adanya pelatihan ini. Mereka menyampaikan bahwa selama ini penentuan harga jual suatu produk yang dihasilkan hanya berdasarkan

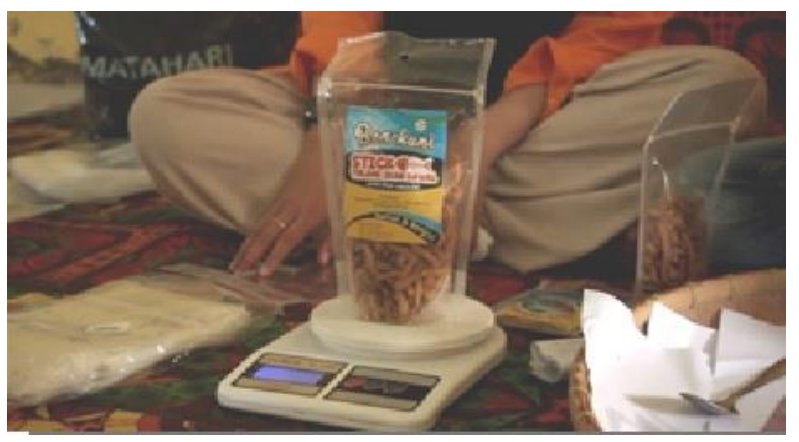

Gambar 6 Penentuan harga pokok produksi. perkiraan atau berdasarkan pengamatan harga pasar, tidak berdasarkan HPPnya.

\section{Pelatihan Strategi Pemasaran Kreatif}

Pelatihan tahap keempat adalah pelatihan strategi pemasaran kreatif. Kegiatan ini dilaksanakan pada 16 Agustus 2019. Pemasaran menurut Kotler (2001) adalah sebagai suatu proses sosial dan managerial yang membuat individu dan kelompok memeperoleh apa yang mereka butuhkan dan inginkan lewat penciptaan dan pertukaran timbal balik produk dan nilai dengan orang lain.

Penciptaan suatu produk baru harus disertai dengan penciptaan pasar dan media pemasarannya. Pembuatan media pemasaran online, terutama melalui media sosial merupakan salah satu strategi pemasaran kreatif saat ini. Menurut Halim (2010) bahwa pemasaran online merupakan bentuk komunikasi baru yang kreatif dimana tidak memerlukan komunikasi tatap muka secara langsung, melainkan dapat dilakukan secara terpisah dari dan ke seluruh dunia melalui media notebook, komputer, ataupun handphone yang tersambung dengan layanan akses internet. Dengan demikian, pemasaran online memperbesar peluang promosi dan pendistribusian yang lebih luas dengan biaya yang lebih efisien. Penggunaan media pemasaran online memungkinkan konsumen dapat langsung memberikan saran dan kritik maupun kepuasannya terhadap produk stik tulang dan abon ikan bawal dan nila.

Pemasaran kreatif juga dimaksudkan untuk meningkatkan kuantitas produk ikan air tawar dan olahannya yang dapat dipasarkan dalam wilayah Propinsi Sulawesi Tenggara (daratan dan kepulauan) serta antar propinsi. Hal ini dapat dilakukan melalui e-marketing serta pemasaran berbasis konsumen. Strategi pemasaran ini akan sangat memudahkan pengelola dan anggota Bumdes Amokuni agar tidak tidak terlalu bergantung pada pedagang pengumpul, serta dapat meningkatkan kekuasaannya dalam menentukan harga jual dan wilayah pemasarannya.

Peserta pelatihan strategi pemasaran kreatif juga difokuskan kepada pengelola dan ibu-ibu anggota aktif Bumdes Amokuni. Perbedaannya, pada pelatihan ini ibu-ibu anggota aktif tersebut didampingi oleh seorang anaknya yang aktif bersosial media. Anak muda ini berperan mendampingi ibunya agar lebih mudah memahami membuat media pemasaran online, juga membantu dalam mengefektifkan pemasaran kreatif secara offline. 
Pada pelatihan ini peserta mempraktikkan membuat instagram bisnis instagram Bon-Kuni (Gambar 7). Instagram ini khusus digunakan untuk mempromosikan dan memasarkan produk-produk Bumdes Amokuni utamanya abon ikan kriuk dan stik tulang ikan.

Strategi pemasaran kreatif juga dilakukan secara offline. Peserta pelatihan diarahkan untuk selalu aktif dalam melakukan pemasaran. Secara offline, peserta pelatihan diarahkan dan dimotivasi untuk aktif menyebarkan brosur, mencari, dan mengikuti berbagai expo atau pameran untuk semakin memperkenalkan produk BonKuni. Pembuatan brosur di tahap awal ini difasilitasi oleh tim pengabdi.

Peserta pelatihan masih menunjukkan respon positifnya hingga di pelatihan yang keempat. Hal ini ditunjukkan dengan semangat peserta untuk mengikuti pameran 17 Agustus se Kabupaten Konawe Selatan (Konsel) yang dilaksanakan keesokan hari setelah pelaksanaan pelatihan keempat ini. Para peserta bersama tim pengabdi segera mempersiapkan produk-produk Bon-Kuni yang akan dipamerkan.

\section{Pendampingan}

Peningkatan keterampilan pengelola dan anggota Bumdes Amokuni dilanjutkan dengan pendampingan dalam melanjutkan dan mengimplementasikan materi-materi yang telah diberikan pada keempat pelatihan yang telah diselenggarakan sebelumnya. Pendampingan merupakan suatu proses pemberian kemudahan (fasilitas) yang diberikan pendamping kepada klien dalam mengidentifikasi kebutuhan dan memecahkan masalah serta mendorong tumbuhnya inisiatif dalam proses pengambilan keputusan, sehingga kemandirian klien secara berkelanjutan dapat diwujudkan (Direktorat Bantuan Sosial 2007)

Beberapa hal yang dilakukan oleh tim pengabdian pada kegiatan pendampingan ini adalah mendampingi pengelola dan anggota aktif Bumdes dalam melakukan proses penyempurnaan perbaikan manajemen usaha Bumdes dan pengimplementasiannya, mengulangi tahapan produksi, pengemasan, dan pemasaran abon ikan kriuk dan stik tulang ikan. Produk-produk tersebut selanjutnya dipasarkan secara online melalui instagram bon-kuni dan secara offline yang diawali dengan keiikutsertaan pada beberapa pameran, yaitu pameran 17 Agustus se Kabupaten Konawe Selatan, pameran Hari Pangan Sedunia di Kota Kendari, dan Pameran pada Seminar Internasional di Fakultas Pertanian Universitas Halu Oleo Kendari (Gambar 8).

\section{SIMPULAN}

Kegiatan pengabdian pada masyarakat yang berupa penyuluhan, pelatihan, dan pendampingan telah meningkatkan pengetahuan dan keterampilan pengelola dan anggota Bumdes Amokuni. Peningkatan pengetahuan dimaksud dalam hal manajemen usaha, peningkatan nilai tambah sumber daya air tawar, penentuan HPP, dan strategi pemasaran kreatif untuk produk ikan air tawar yang akan dihasilkan. Peningkatan keterampilan dimaksud berupa keterampilan membuat konsep manajemen usaha, mengolah ikan bawal dan nila menjadi abon ikan kriuk dan stik tulang ikan dengan lima varian rasa (rasa original, $\mathrm{BBQ}$, pedas manis, balado, dan jagung bakar), menentukan HPP, dan memasarkan diversifikasi produk ikan air tawar tersebut secara online dan offline.

\section{UCAPAN TERIMA KASIH}

Ucapan terima kasih disampaikan kepada Universitas Halu Oleo (UHO) yang telah memberikan pendanaan internal bagi kegiatankegiatan pengabdian masyarakat terintegrasi KKN Tematik, dan kepada Lembaga Penelitian dan Pengabdian pada Masyarakat Universitas Halu Oleo (LPPM-UHO) yang telah memfasilitasi dan mendukung kegiatan pengabdian ini.

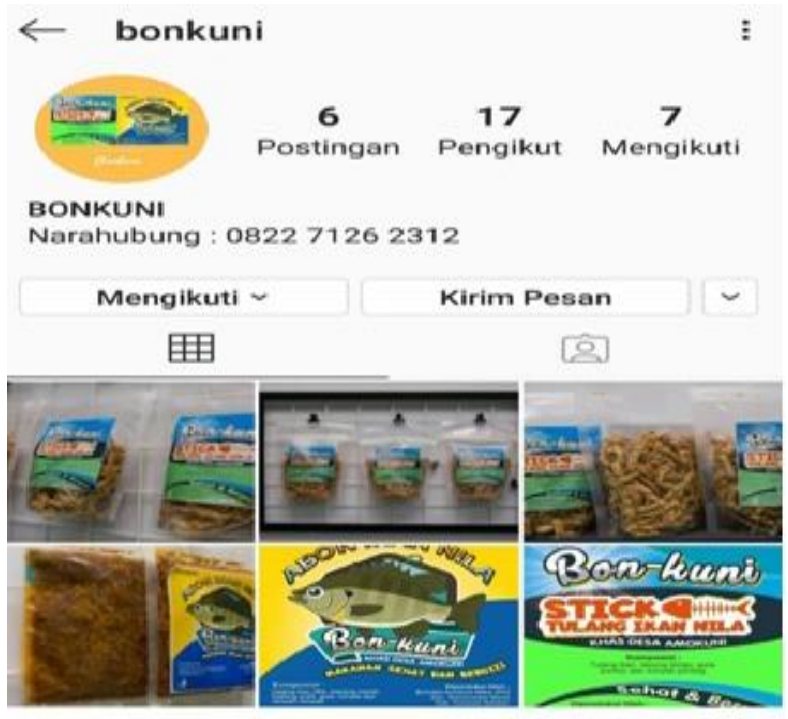

Gambar 7 Instagram bon-kuni. 

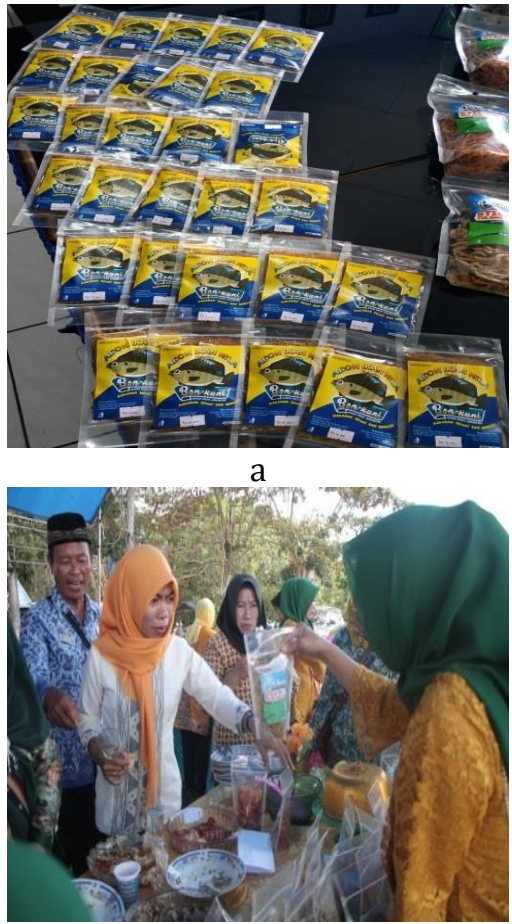

d

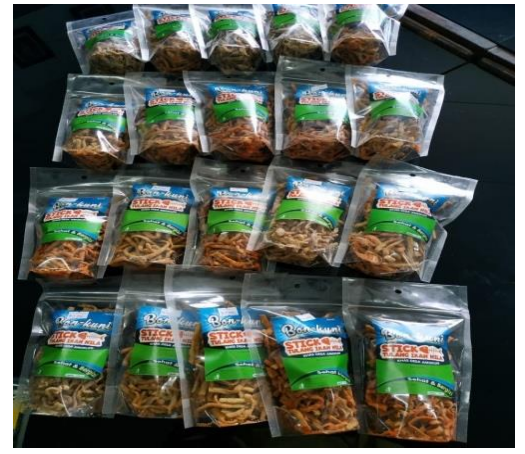

$\mathrm{b}$

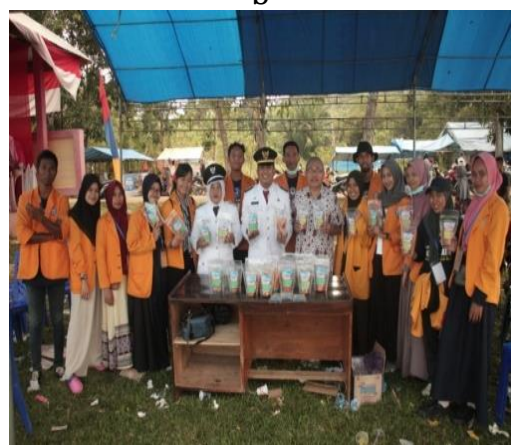

$\mathrm{e}$
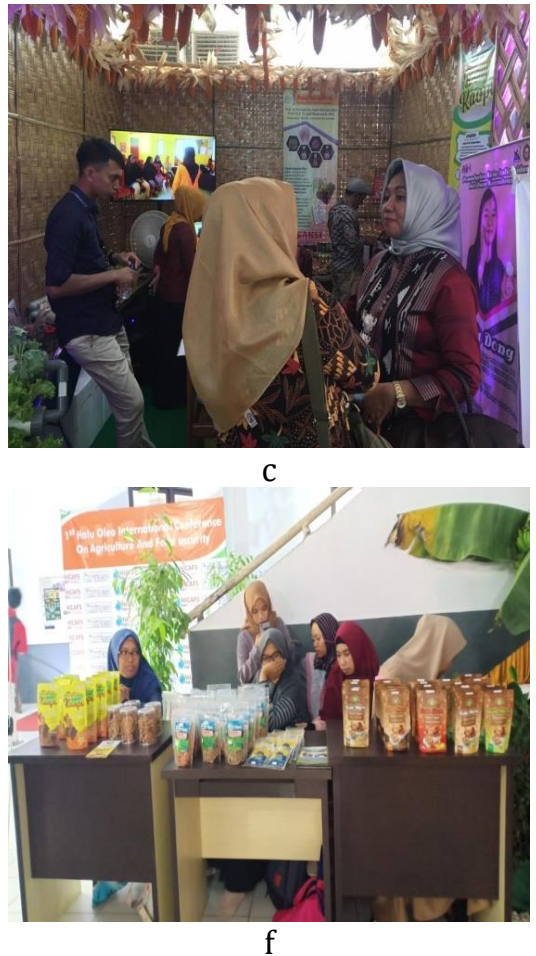

Gambar 8 a) Produk abon ikan; b) Produk stik tulang ikan; c) Pendampingan pada pameran hari pangan sedunia di Kota Kendari; d dan e) Pendampingan pada pameran 17 Agustus s-Kabupaten Konawe Selatan; dan e)Pendampingan pada pameran seminar internasional di Fakultas Pertanian, Universitas Halu Oleo Kendari.

\section{DAFTAR PUSTAKA}

Berdesa. 2017. Badan Usaha Milik Desa (BUMDES). [Internet]. [Diakses pada: November 2018]. Tersedia pada: http://www.berdesa.com/.

Direktorat Bantuan Sosial. 2007. Pedoman Pendamping Pada Rumah Perlindungan dan Trauma Center. Jakarta (ID): Departemen Sosial RI.

Fausayana I, Rosmawaty, Akhyar. 2019. Peningkatan Margin Kontribusi dan nilai Tambah Aneka Produk Olahan Rumput Laut di Desa Bungin Permai, Konawe Selatan, Sulawesi Tenggara. Agrokreatif Jurnal Ilmiah Pengabdian kepada Masyarakat. 5(1): 71-76. https://doi.org/10.29244/agrokreatif.5.1.7176

Halim A. 2010. Dasar-dasar Akuntansi Biaya. Edisi 4. Yogyakarta (ID): BPFE.

Hansen dan Mowen, 2006. Akuntansi Manajemen. Jakarta (ID): Salemba Empat.

Hartoyo, Koswara S, Sulassih, Megawati LZ. 2019. Peningkatan Nilai Tambah Usaha Olahan Keripik Pisang di Desa Tenajar, Kabupaten
Indramayu, Jawa Barat. Agrokreatif Jurnal Ilmiah Pengabdian kepada Masyarakat. 3(2): 251-257.

https://doi.org/10.29244/agrokreatif.5.3.25 $1-257$

Kotler A. 2001. Prinsip-prinsip Pemasaran, Edisi keduabelas, Jilid 1. Jakarta (ID): Erlangga.

Kusnayadi H, Merdekawati A, Kusmawardani W. 2019. Pelatihan dan Pendampingan Kelompok Mitra PKM di Desa Leseng, Kecamatan Moyo Hulu, Kabupaten Sumbawa. Agrokreatif Jurnal Ilmiah Pengabdian kepada Masyarakat. 3(2): 96-102.

https://doi.org/10.29244/agrokreatif.5.2.96102

Levis. 1996. Komunikasi Penyuluhan Pedesaan.Bandung (ID): PT Citra Aditya Bakti.

Mardikanto T. 1993. Penyuluhan Pembangunan Pertanian. Surakarta (ID): Sebelas Maret University Press.

Mulyadi. 2012. Akuntansi Biaya. Sekolah Tinggi Ilmu Manajemen. Yogyakarta (ID): YKPN.

Nuzuliyah L. 2018. Analisis Nilai Tambah Produk Olahan Tanaman Rimpang. Industria: Jurnal Teknologi dan Manajemen Agroindustri. 7(1): 
31-38.

https://doi.org/10.21776/ub.industria.2018. 007.01.4

Ohoiwutun MK, Ohoiwutun EC, Hasyim CV. 2017. Peningkatan Kualitas Ikan Teri Kering di Desa Sathean, Kecamatan Kei Kecil, Kabupaten Maluku Tenggara. Agrokreatif Jurnal Ilmiah Pengabdian kepada Masyarakat. 3(2): 150156.

https://doi.org/10.29244/agrokreatif.3.2.15 $0-159$

Peraturan Menteri dalam Negeri Nomor 39 Tahun 2010. https://jdih.bpk.go.id/?p=20949. Diakses pada Januari 2020.

Rahman S. 2015. Analisis Nilai Tambah Agroindustri Chips Jagung. Jurnal Aplikasi Teknologi Pangan. 4(3): 108-111. https://doi.org/10.17728/jatp.v4i3.136
Robert LM. 2002. Manajemen Sumber Daya Manusia. Jakarta (ID): Salemba

Siswanto HB. 2005. Pengantar Manajemen. Jakarta (ID): Bumi Aksara.

Soe'oed RDF. 1999. Proses Sosialisasi. Dalam Ihromi TO. Bunga Rampai Sosiologi Keluarga. Jakarta (ID): Yayasan Obor Indonesia.

Sudiyono A. 2002. Pemasaran Pertanian. Malang (ID): UMM Press Malang.

Terry GR. 2009. Prinsip-prinsip Manajemen. Jakarta (ID): Bumi Aksara.

Udhyn. 2017. Inilah Desa dengan Potensi Pertanian Terbaik di Konsel. [Internet]. [Diakses pada: Agustus 2018]. Tersedia pada: https://anoatimes.id/inilah-desa-denganpotensi-pertanian-terbaik-di-konsel/. 